九病虫研会報 $48 ： 37-41(2002)$

Kyushu Pl. Prot. Res. $48: 37-41$ (2002)

\title{
鹿児島県東串良町で問題となった キバナハウチワマメ栽培地の裸地化要因
}

\author{
福永求*・西岡 稔彦・田中章 \\ （鹿児島県農業試験場大隅支場）
}

\begin{abstract}
Factors causing bare ground in fields of Lupinus lutens L. in Higashikushira,
Kagoshima Prefecture. Motomu Fukunaga, Toshihiko Nishioka and Akira Tanaka

(Osumi branch. Kagoshima Agricultural Experiment Station, 4938. Hosoyamada, Kushira,

Kagoshima 893-1601. Japan)
\end{abstract}

Key words : bare ground, growth inhibition, Lupinus lutens L.

ルピナス (ハウチワマメ) 属はマ・メ科に属して世界各 地に約300種が存在し，国内では緑肥や観賞用として利 用されている(憍本貞夫, 1986)。鹿児島県束串良町の 耕作地では、1970年代からルピナス（ハウチワマメ）が 緑肥作物として栽培されてきた。東串良町役場（以下町 と言う）はルピナスの開花期の美しい景観に着目し， 1989年から同町柏原海岸の松林之海に挟まれた幅 $50 \mathrm{~m}$ 長 さ $2 \mathrm{~km}$ の砂地（面皘約10ha）で, ルピナス属の一種で あるキバナハウチワマメ（Lupinus lutens L.）を栈塯し (播種：10月下旬 11月下旬, 開花： 3 月 4月), 「ル ピナスフェスティバル」を開催してきた。キバナハウチ ワマメの生育は，1993年頃までは良好であったが，それ 以降，発芽後間もない頃から生育後期にかけて地上部が 消失し久株となる証状（以下裸地化と言う）が発生した。 町は, 肥料, 堆肥, 除草剂散布の有無扔よび播種時期の 早晚の影響を調盗したが、いずれも裸地化の要因とは特 定できず，1994年以降は堆肥，肥料，除草揧を施用せず に栽培してきた。裸地化はそれ以降も発生したため, 1996年 4 月当支埸に診断依頼があり，原因究明と数種殺 菌剤による防除効果試騃を行ったが，原因は明らかにで きず，殺菌剮の防除効果も認められなかった〈制田ら。 未発表)。さらに, 2000年 3 月, 裸地化が著しかったこ とから，当支場に再度診断依頼があり，原因究明に取り 組むことになった。原因究明に当たり，土壤の理化学性

*現在：川薩農業改良普及センター 鹿児島県川内市噮之城214

* Present address:Sensatsu Agricultural Improvement and Advisory Center, Sendai, Kagoshima 895-0041. Japan
について調查して頂いた，当支場土塞改良研究室の餅田 研究員 (現在, 種子島農業改良普及センター) に厚くお 礼申し上げる。

\section{調查および試験方法}

\section{調查 1 ，発生実態}

2000年 3 月～ 5 月，キバナハウチワマメ栽培地全体に おける裸地化の発生と進展状況を達観により調查した。 また、3月30日には一部に約 $18 \mathrm{~m}^{2} の$ 防護ネットを張っ た区を設け，播種後のウサギ等による食害状況も併せて 調查した。

調査 2.土壤の理化学性, 土壤病原菌および線虫相

2000年3月29日, 柏原海岸のキバナハウチワマメ茂培 地において，達観調查により健全抢よび生育不良と判定 した計 6 地点から土堙を採取し， $\mathrm{pH} ＼textrm{E C ， ア ン モ ニ ア ~}$ 態窒素 $\left(\mathrm{NH}_{4}-\mathrm{N}\right)$, 硝酸態空素 $\left(\mathrm{NO}_{3}-\mathrm{N}\right)$ を分析古ると ともに、ベルマン法（土壤 $20 \mathrm{~g}, 25^{\circ} \mathrm{C} ， 72$ 時間）により 土壤線虫相を調查した。さらに，健全㧍よび生育不良株 合わせて 20 株を採取し，地際荎部から切片を取り，水道 水の掛け流しによる表面殺菌後素寒天培地に置床し， $25^{\circ} \mathrm{C}$ で 3 日間培盖して菌の分離を行った。

調查 3. 裸地化の発生および生育の差異と栽培管理法 の関係

町が柏原海岸で主催した「ルピナスの花コンタール」 に参加した10個人・団体の栽培したキバナハウチワマメ について，2001年4月16日に下記（ア〜ウ）の調査を行 い，栽培日誌を基に栽培管理と裸地化との関係を検討し た。種子は町が配布し、栽培管理は栽培者一任であった。 ア、達観による花数、桑葉数および被覆度の総合判定 
（最高：5，最低：1）

イ. 各区20株の草丈と花梗長の測定

ウ. 1 畦 $5 \mathrm{~m}$ 当たりの健全株数調査 ( 2 か所)

試験 1.土壤消毒および生育期の殺菌㓮灌注処理

柏原海岸において, 反復なしでクロルピクリンくん蒸 版消毒区（7 a）および無消毒区（7 a）を設けて土壤 消毒試験を行い, 裸地化に対する病原菌の関与を検討し た。試験区の周囲には，ウサギによる食害を防ぐため に防護ネットを張った。消毒作業は，2000年11月 2 日に $20 l / 10$ a 忆引式消毒機で行い，被覆処理した。11月 21日にガス抜きを行い，翌日にキバナハウチワマメを条 播きした（条間 $50 \mathrm{~cm}$ ，株間 $2 \sim 3 \mathrm{~cm}$ )。播種 54 日およ び79日後に各区 7 箇所（松林側 4 か所, 海側 3 か所, 1 箇所は 1 畦 $5 \mathrm{~m}$ ）の枯死株率を調查した。

また，キバナハウチワマメの生育期間中に，上記の消 毒区ならびに無消毒区それぞれで，キャプタン水和剂， ヒドロキシイソキサゾール液剤 (800倍， $3 \mathrm{l} / \mathrm{m}^{2} ， 2$ 月 9 日から約 1 週間間隔で 3 回), エクロメゾール乳剂 (1000倍， $3 \mathrm{l} / \mathrm{m}^{2} ， 2$ 月16日から約 1 週間間隔で 3 回) を灌注処理した $\left(12.5 \mathrm{~m}^{2} /\right.$ 区 $)$ 。各薬剂灌注日および最 終灌注日の 1,2 週間後の計 $4 \sim 5$ 回, 各区の健全株率 を調查した。

\section{結果}

\section{1. 発生実態}

2000 年 3 月には, キバナハウチワマメ栽培地約 $10 \mathrm{ha}$ のうち 80 ～90\%の面積で地上部が消失し, 裸地状態と なった。特に，松林側では被害が激しかった。地際から 切断された株が多く，周囲にはウサギの䔬が多く見られ た。防護ネット区の中は全く食害されなかったのに対し， 防護ネットの外では食害による被害が大きかった（第 1 図)。5 月 1 日夜, キバナハウチワマメ栽培地を徘䧃す るウサギを目撃確認した。しかし，防護ネット区内でも 発芽直後〜本葉が数枚展開する頃に葉が赤紫色を帯びて, 生育不良となり枯死する株も確認された（第 2 図）。生

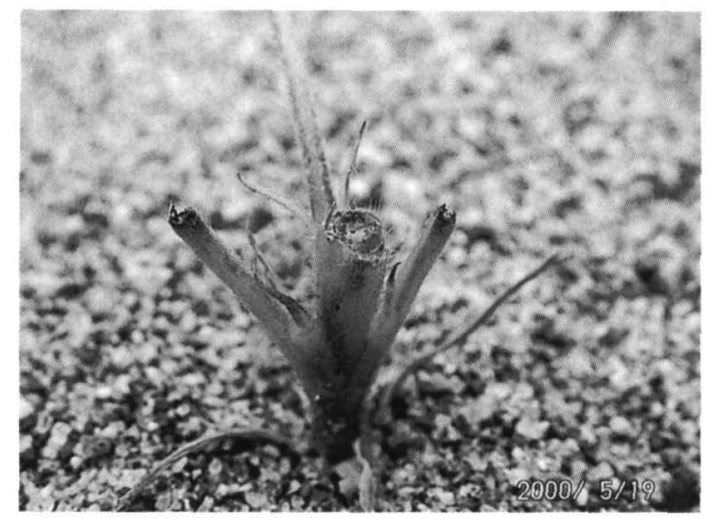

第 1 図 生育初期にウサギに食害されたキバナハウチ ワマメ

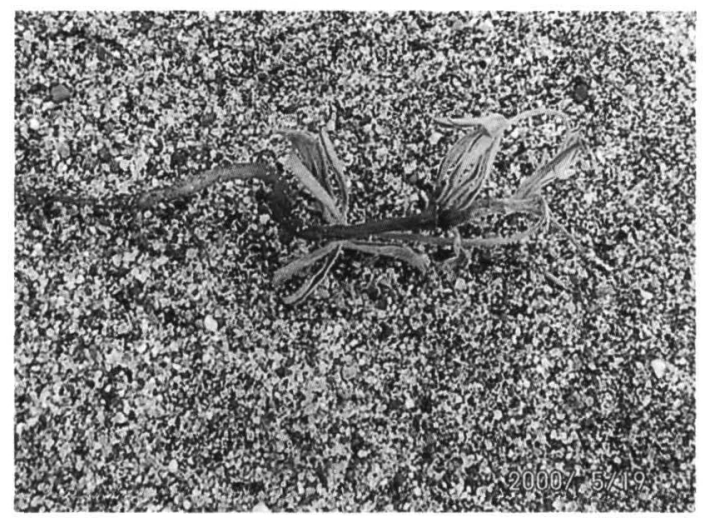

第 2 図 生育不良となり枯死したキバナハウチワマメ (播種 50 日後)

育不良株の地際茎部は褐変しており，健全根も少なかっ た(達観)。

\section{2. 土壤の理化学性および土壤病害, 線虫相}

調查土壤の $\mathrm{pH}, \mathrm{EC}, \mathrm{NH}_{4}-\mathrm{N}$ 抢よび $\mathrm{NO}_{3}-\mathrm{N}$ のいずれ にも異常值は認められず，健全株のある地点と生育不良 地点とでは差異がなかった。さらに, いずれの地点から も，ネコブセンチュウおよびネグサレセンチュウ等の有 害線虫は検出されなかった（第 1 表）。一方，健全株と

第 1 表 キバナハウチワマメ栽培地の土壌（砂）の理化学性と有害線虫数（2000年 3 月 29 日土壤採取）

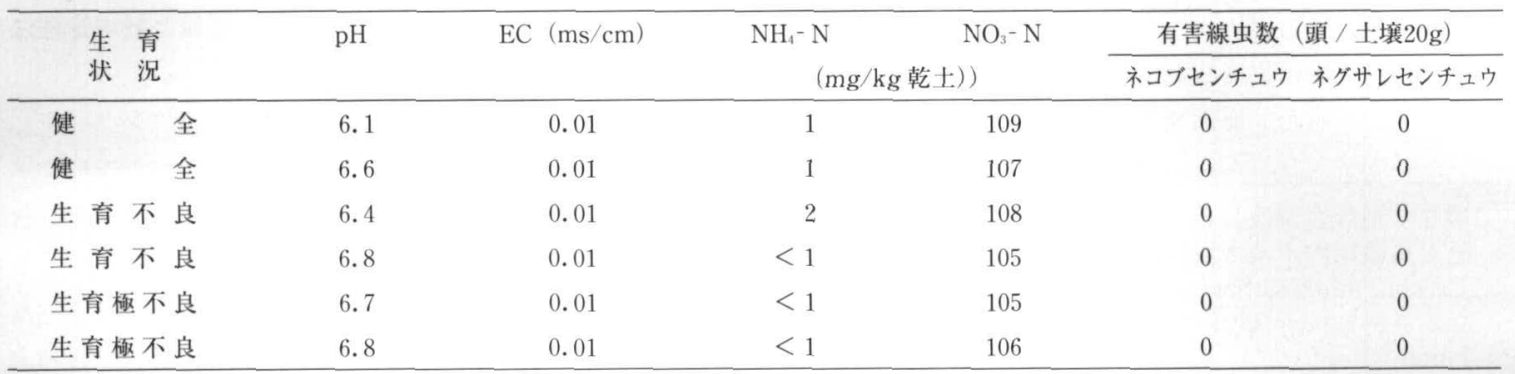


生育不良で地際茎部の褐変した株のいずれからも Fusarium 属菌が高頻度に分離された（第 2 表）。分離 菌の病原性は未確認である。

第 2 表 キバナハウチワマメからの分離糸状菌類 (2000年3月29日分離)

\begin{tabular}{|c|c|c|c|}
\hline & 株（切片） & Fusarium spp. & 不明 菌 \\
\hline 全 & 4 & 4 & \\
\hline 生 育不良 & 12 & 11 & 4 \\
\hline 生育極不良 & 4 & 3 & 1 \\
\hline
\end{tabular}

\section{3. 裸地化の発生および生育の差異と栽培管理法の関 俰}

調查对象者10個人・団体 $(\mathrm{A} \sim \mathrm{J})$ のキバナハウチワ マメの栽培管理法と生充状況を第 3 玟にまとめた。栽培 管理は, 土作り, 播種方法, 病害虫等の防除を綿密に 行った $\mathrm{A}, \mathrm{B}$ と, そうでないもの $(\mathrm{C} \sim \mathrm{J})$ とに大別さ 礼た。ギナハウチワマメの生育も，A，Bは良好で開 花も多く，C—Jは欠株が多く花も少ないなど大差が あった。達観調查で最良のA， Bの草丈は $84 \mathrm{~cm} て ゙$ 著しく 高く，花梗長も他より著しく長く $19.8 ， 14.2 \mathrm{~cm}$ であった。 一方，I，Jの草丈は A， Bの約半分の $40 \mathrm{~cm}$ 程度であっ た。1晆 $5 \mathrm{~m}$ 当たりの健全株数は $\mathrm{A}$, Bで多く, その他 は少なかった。播種は，10月31日〜11月22日の間で行わ
れていた。11月上旬が多かったが，播種時期の違いによ る久株および生育良否の差異は認められなかった。健全 かつ達観調査で最良の A，Bに特徽的な栽培管理は，媣 耕, 堆肥と苦土石灰抢よび化学肥料の施用, 種子への根 粒菌の接種，追い播き，追肥であった。

\section{4.土壤消毒および生育期の殺菌剤灌注処理}

土壤消毒の有無に関わらず，キバナハウチワマメは正 常に発芽した。

土袞消毒試験区の枯死株率の推移を第 4 表に示した。 播種54日および79日後いずれの枯死株率も，消毒区が無 消毒区より高かった。消毒区の播種54日後で松林側の枯 死株率が高かったが，その他は松林側と海側の枯死株率 に茥はなかった。クロルピクリンくん苲剤消毒は裸地化 を抑制できなかった。

殺菌剂灌注試験区の健全株率の推移を第 3 図に示した。 いずれの殺菌剤灌注区でも，健全株率は2月23日までは 漸減し, それ以降は最終薬椷処理の 1 週間後まで微減し た。減少割合は無処理区と同等であった。殺菌剤灌注区 の健全株率は，最終的に処理前の60\%程度となり無処理 区と同等であった。キャプタン水和剂，ヒドロキシイソ キサゾール液片, エクロメゾール乳剤の灌注処理は, 裸 地化の発生を抑制できず防除効果は認められなかった。

また，本試験中の2000年12月～2001年 1 月，試験区お よび周辺の栽培地で, 多数のカラスが萌芽した芽を種子

第 3 表 コンクール参加者によるキバナハウチワマメの栽培管理法と生育状況（生育調查：2001年 4 月 16 日）

\begin{tabular}{|c|c|c|c|c|c|c|c|c|c|c|}
\hline 粗 場 名 & A & $\mathrm{B}$ & $\mathrm{C}$ & $\mathrm{D}$ & $\mathrm{E}$ & $\mathrm{F}$ & $\mathrm{G}$ & $\mathrm{H}$ & I & J \\
\hline \multicolumn{11}{|l|}{ 生育状況 } \\
\hline 5 段階評価 & 5 & 5 & 4 & 3 & 3 & 2 & 2 & 2 & 2 & 1 \\
\hline 草丈（cm） & 84.5 & 84.2 & 65.8 & 64.9 & 61.5 & 54.2 & 52.8 & 61.3 & 43.4 & 38.0 \\
\hline 花梗辰（cm） & 19.8 & 14.2 & 10.4 & 7.1 & 10.2 & 10.7 & 7.1 & 10.7 & 10.2 & 6.6 \\
\hline 晆 $5 \mathrm{~m}$ 当たり株数 & 72 & 67 & 64 & 78 & 35 & 65 & 53 & 39 & 28 & 24 \\
\hline \multicolumn{11}{|l|}{ 土作り } \\
\hline 深耕 & 0 & 0 & $x$ & $x$ & 0 & $x$ & $x$ & $x$ & $x$ & $x$ \\
\hline 堆肥 $(\mathrm{kg} / 10 \mathrm{a})$ & 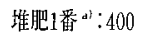 & 同 : 170 & 同 : 130 & 同 : 50 & 同 : 250 & $x$ & $\times$ & 鶏䔬：20 & $x$ & $x$ \\
\hline 苦土石灰 $(\mathrm{kg} / 10 \mathrm{a})$ & 250 & 330 & $\times$ & 50 & $\times$ & $x$ & 33 & $\times$ & $x$ & $x$ \\
\hline 化学肥料（kg/10a） & 50 & 33 & $x$ & $x$ & 100 & $x$ & 66 & $\times$ & $x$ & $x$ \\
\hline \multicolumn{11}{|l|}{ 播種方法 } \\
\hline 播種日 & 11月 4 日 & 11月 4 日 & 11月13日 & 10月31日 & 11月 5 日 & 11月 4 日 & 11月4日 & 11月13日 & 10月31日 & 11月22日 \\
\hline 根粒菌 & 0 & 0 & x & x & $\times$ & $\times$ & x & $\times$ & $x$ & $\times$ \\
\hline 追い播き & 0 & 0 & $x$ & $x$ & $x$ & $x$ & $x$ & $x$ & $x$ & $x$ \\
\hline \multicolumn{11}{|l|}{ その他 } \\
\hline 追肥 & 0 & 0 & 0 & $x$ & $x$ & $x$ & 0 & $x$ & $x$ & $x$ \\
\hline 雱虫駆除 & 0 & $\mathrm{O}$ & $x$ & $x$ & $x$ & $x$ & $x$ & $x$ & $x$ & $x$ \\
\hline ウサギ防除 & 0 & 0 & 0 & $x$ & $x$ & $x$ & $x$ & $x$ & $x$ & 0 \\
\hline 鳥害駆除 & 0 & 0 & $\times$ & $x$ & $x$ & 0 & $x$ & $x$ & 0 & $\times$ \\
\hline
\end{tabular}

a) 堆肥 1 番 (烌ジャパンファーム) の組成：鴊䨋, 翵死骸, 油粕 
第 4 表 土壌消毒試験区におけるキバナハウチワマメの枯死株率

\begin{tabular}{|c|c|c|c|c|c|}
\hline \multirow{2}{*}{ 区 } & & \multicolumn{2}{|c|}{ 播種54日偻（1月15日） } & \multicolumn{2}{|c|}{ 播種79日後（2月9日） } \\
\hline & & 松林側 & 海 侧 & 松林側 & 游 側 \\
\hline \multirow[t]{2}{*}{ クロルピクリン消表区 } & 調查株数 & 91.5 & 73.3 & 66.3 & 65.0 \\
\hline & 枯死株率 $(\%)$ & 17.4 & 9.7 & 52.1 & 54.9 \\
\hline \multirow[t]{2}{*}{ 無消毒区 } & 調查株数 & 95.3 & 64.7 & 85.5 & 58.3 \\
\hline & 枯死株制 $(\%)$ & 10.5 & 12.1 & 32.4 & 35.7 \\
\hline
\end{tabular}

数值は松林側 4 地点, 海側 3 地点の平均值を示し, 1 地点は 1 時 $5 \mathrm{~m}$
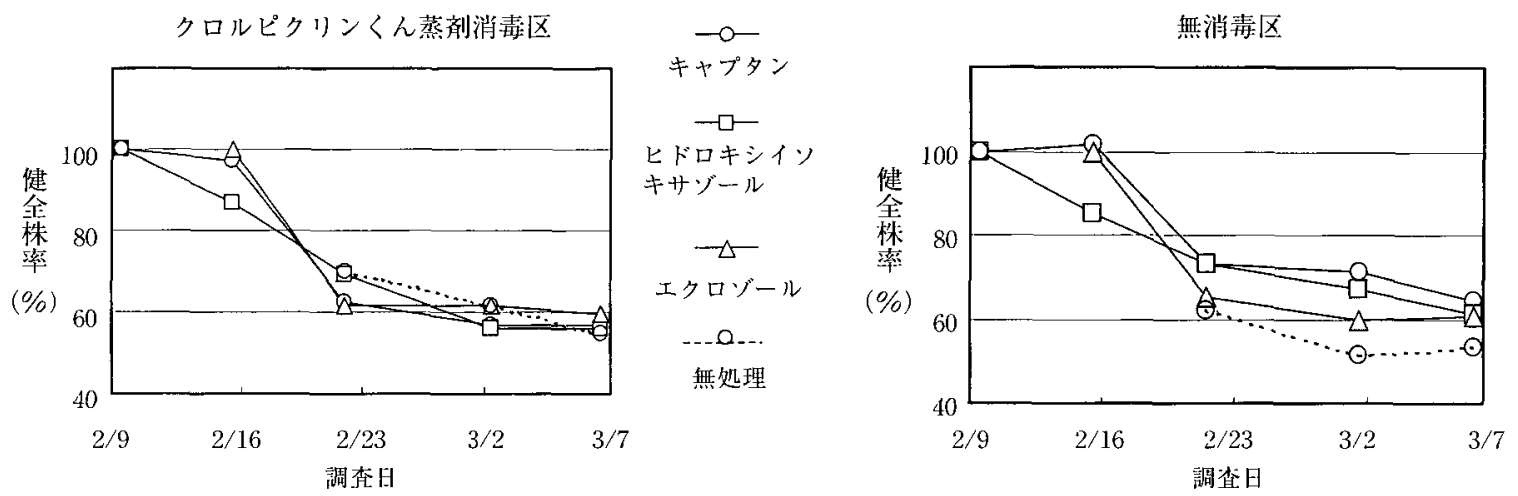

第 3 忷 クロルピクリンくん蒸剤消毒拉よび無消毒区における各種殺菌剤泎注処理後の健全株率の推移 健全株率は2月9日（エクロメゾール乳郕は2月16日）を100としたときの值 2月9日および16日から莯㘊処理

ごと食べているのを目撃確認した。

\section{考察}

東串良町のキバナハウチワマメ栽培地に打ける裸地化 の一要因として, 調査 1 と試験 1 の結果からウサギや力 ラスによる食害が明らかになった。特にウサギの影響は 大きいと考えられる。さらに，食害以外にも，生育不良 となり杜死して裸地となることも明らかになった。これ は土壤に原因があると考元られたが，土蛮の理化学性 $\left(\mathrm{pH}, \mathrm{EC}, \mathrm{NH}_{4}-\mathrm{N}, \mathrm{NO}_{3}-\mathrm{N}\right)$ や土㥽線虫相（ネコブセ ンチュウ，ネグサレセンチュウ）の調查結果から，塩害 や線虫害は裸地化の要因ではないと考えられる。

キバナハウチワマメはマメ科植物であり，地力の低い 土壤でも根粒菌との共生により生省可能と言われる。し かし，裸地化の一要因は，土作りを含めた栽培管理の不 備と砂地の低い地力が大きく影響していると考えられる。 調査 3 で堆肥，苦土石灰，化学肥料が充分に投入された 栽培地のキバナハウチワマメの生育が良く，久株もほと んど見られなかったのに対し，こ机らが投入されていな い栽培地では生育が悪く欠株も多かった(第 3 表)。さ らに, 町は1994年以降, 堆肥や化学肥料を使用していな
い。また，県民の森公園（始良町、1996年調查)，慈眼 寺公園（碓児島市，1999年調査），フラワーパーク(山 川町，1999年調查) 等の県内のルピナス溨培地では，特 に栽培上の問題は生じていないが, 大崎町横瀨の砂地で は一部で生育が悪く裸地となり問題となっている(1999 年調沓，以上町による）ことがその理由として考えられ る。

以上のことから，束串良町柏原海岸のキバナハウチワ マメの裸地化は，ウサギやカラスによる食害と土作りを 含む耕培管理の不備との複合的な要因が関与していると 考えられる。

なお，調查 1 でFusarium 属菌が健全および生育不良 株から高頻度に分離された（第 2 表）ことから，土壤病 原菌等の関与も否定できない。「日本植物病名目録」(日 本植物病理学会編，2000）扝よび「日本植物病害大事 典」(岸國平編，1998）によ机ば，ルピナス（ハウチワ マメ）に萎ちょう・枯死を引き起こす族害として，立枯 病 (Fusarium oxysporum, Fusarium sp.), 茎腐病 (Rhizoctonia solani) , 腰折病 (Pythium $\mathrm{sp}$.) が記载さ れている。しかし、クロルピクリンくん蒸剂消毒ならび に各種殺莐剤の灌注処理でも裸地化を抑制できなかった 
（第 3 図、第 4 表）ことから,引き続いて栽培管理の影 響と土溒病原菌等の関与との両面から, 接種試験を行う などして、さらに詳しく検討していきたい。

\section{摘要}

1。鹿児島県東串良町の柏原海岸において，1994年頃 から発生しているキバナハウチワマメ栽培地の裸地化の 原因を調査した。

2. 裸地化の一要因として，海岸の松林に生息するウ サギおよびカラスの食害が明らかになった。特に，ウサ ギの影響は大きいと考えられた。

3。一方，食害が認められないにも関わらず，発芽後 一本葉が数枚展開する頃に生育不良となり, 地際茎部が 褐変して枯死し，裸地化する場合があることも判明した。

4. 栽培土壤の $\mathrm{pH}, \mathrm{EC}, \mathrm{NH}_{4}-\mathrm{N}, \mathrm{NO}_{3}-\mathrm{N}$ および線 虫相を調查した結果, 異常値は認められなかったことか
ら，塩害ならびに土壤線虫は裸地化の要因ではないと考 えられた。

5.クロルピクリンくん蒸凨による土堙消毒抢よび各 種殺菌郕の灌注処理でも、裸地化を抑制できなかった。

6. キバナハウチワマメの栽培管理と生育良否の関倸 を調查した結果, 土作りを含めた栽培管理の不備が, 裸 地化の一要因であることが考えられた。

\section{引用 文 献}

橋本貞夫（1986）ルピナス. 花异園芸の事典. 朝倉書 店：pp. 65-66.

岸國平編（1998）日本植物病害大事典. 全国農村教育協 会 (東京) : pp. 1276.

日本植物病理学会編（2000）日本植物病名目録, 初版. 日本植物病理学会 (東京) : pp. 857.

(2002年 4 月30日受領；8 月30日受理) 